\title{
THE EFFECTIVENESS OF USING VOCATIONAL-BASED TEACHING MATERIALS FOR SCIENTIFIC WRITING TO IMPROVE ACADEMIC WRITING SKILLS OF POLYTECHNIC STUDENTS
}

\author{
Moh. Thamrin", Achmad Sjaifullah, dan Umi Anis Ro'isatin \\ (Malang State Polytechnic)
}

\begin{tabular}{|c|c|}
\hline A R T I C L E I N F O & A B S T R A C T \\
\hline $\begin{array}{l}\text { Keyword: } \\
\text { teaching material, } \\
\text { scientific paper, } \\
\text { vocational }\end{array}$ & $\begin{array}{l}\text { This study aims at yielding teaching materials for vocational-based scientific paper } \\
\text { writing that can improve academic writing skills as a focus in Indonesian Language } \\
\text { courses for Polytechnic students. Particularly, it is aimed at describing the results of (1) } \\
\text { evaluation (product test) which consists of expert tests and field tests, and (2) product } \\
\text { effectiveness test. The research method used was a modification of the R2R2 } \\
\text { development model (recursive, reflective, design, and development and RDR } \\
\text { (research, development, research) which resulted in the following stages: a preliminary } \\
\text { study, selection of design, design development, and product effectiveness test. Review } \\
\text { gained from the experts and practitioners demonstrated that the teaching material for } \\
\text { writing a scientific paper is in accordance with the characteristics of polytechnic } \\
\text { students because it emphasizes practical activities. The teaching materials have special } \\
\text { features in terms of presentation. The teaching materials have fulfilled their graphic } \\
\text { feasibility so that their readability is stated very well. The t-test analysis shows that the } \\
\text { teaching materials for vocational-based scientific paper writing are effective to } \\
\text { improve the students' academic writing skills. }\end{array}$ \\
\hline
\end{tabular}

\section{INTRODUCTION}

Teaching materials can serve as a strategic medium in transforming knowledge, skills, and values of life, culture, and character (Suyitno, Susanto, Kamal, \& Fawzi, 2017). They can also provide an immense contribution to the achievement of students' learning goals. The World Bank (1989) report, for example in the Indonesian context, that the level of ownership of teaching materials and other facilities is positively correlated with the achievement of learning goals. The World Bank's report is in line with the results of a study conducted by Heyneman et al. (in Thamrin, 2014) stating that there is a significant correlation between the provision of teaching materials and the students' achievement. There is not even something that has a greater influence on the content and implementation of learning activities than what the teaching materials can do (Patrick, 1988; Cunningswort, 1995). In short, around the world, teaching materials play a major role in learning at all levels of education in classroom-based situations.

Teaching materials for scientific paper writing for polytechnic students and polytechnic education have interrelated relationships. The characteristics of the teaching materials are constructed based on the characteristics of polytechnic education. Likewise, the characteristics of the teaching materials for writing scientific works should be arranged based on the characteristics of teaching materials particular to polytechnic education. Hence, it can be said that describing the characteristics of polytechnic education becomes very important as a basis for determining the characteristics of the teaching materials designed for vocational-based scientific paper writing.

\footnotetext{
${ }^{*}$ Corresponding author.

E-mail addresses: thamrin.ham@gmail.com (Moh. Thamrin)
}

ISSN : 2597-7385 (Online) - ISLLAC : Journal of Intensive Studies on Language, Literature, Art, and Culture is licensed under Creative Commons Attribution-ShareAlike 4.0 International License (http://creativecommons.org/licenses/BY/4.0/). 
The relationship of teaching materials to scientific paper writing with polytechnic education and teaching materials for polytechnic students as described above can be more clearly seen in the following figure.

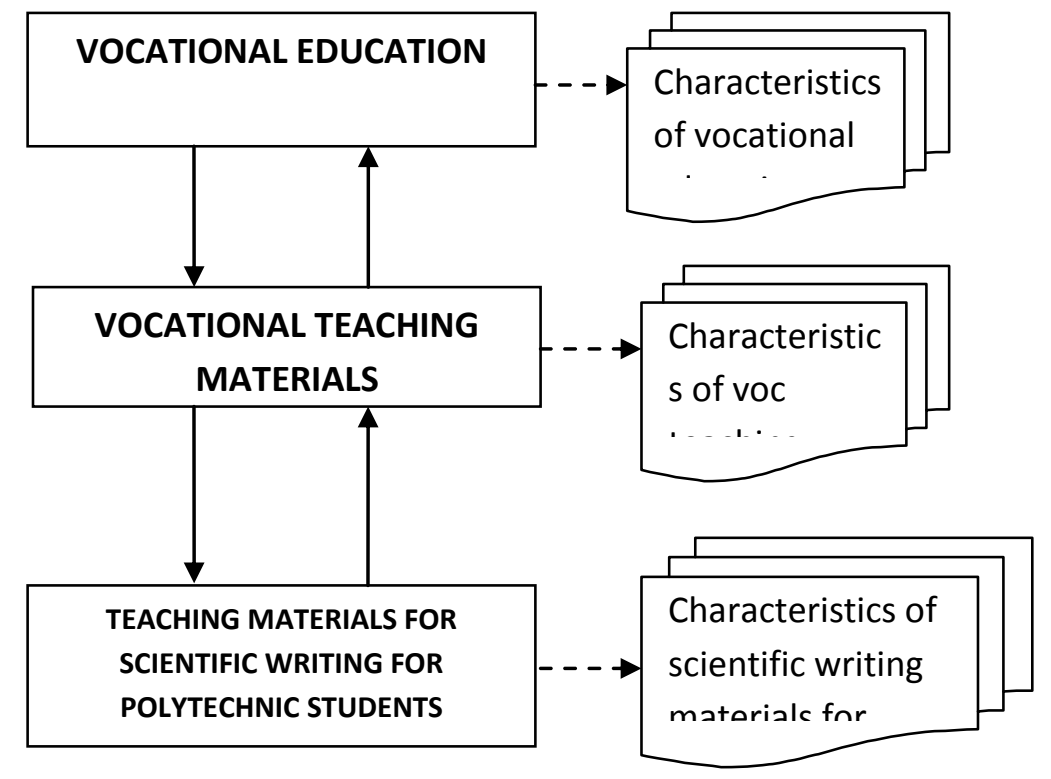

Figure 1: The Interrelationship of Teaching Materials and Polytechnic Education (Thamrin, 2014)

Referring to the interrelationship between the three main components of teaching materials in polytechnic education, the characteristics of teaching materials for vocational-based scientific paper writing are as follows.

1) The teaching materials are described based on competencies and learning indicators to write the intended scientific works.

2) Understanding the nature of scientific work is carried out by observing concept maps, reading theories, and observing images of scientific works.

3) The observations through the exposure of images of scientific works are intended as a means for students to understand the form of a scientific work that can be used as a model product.

4) The exposure to steps to write scientific work that can be used by students as standard operational procedures (POS) in the practice of writing scientific papers is provided.

5) Evaluation of the results of the practice can be carried out independently by students and lecturers by utilizing assessment guides in the form of prepared instruments

6) The learning is student-centered and done with elements of fun.

When the students are involved in the activity of observing images, they can discuss the results of the activities with other students and the results are presented to other students. Hence, the students will have an in-depth understanding of scientific work writing. The student's understanding of scientific work will get stronger because the lecturer would provide reinforcement following the results of the learning activities carried out by the students. In the practice of writing, the students are guided by the steps of writing scientific work. The final results are expected to be more perfect after the students revise the scientific papers based on the given guidelines.

There are two concepts that can be used as a basis for describing scientific work writing, namely, the concept of writing and scientific work itself. Writing is a form of communication-based on an active and constructive process of thinking to express ideas, opinions, feelings, desires, willingness, and information into written forms conveyed to others by using effective language. Such an understanding is in line with the opinion of MacArthur (2007) about writing, that is writing is a tool to convey one's ideas and opinions. Akhadiah (2001: 16) also asserts that writing is an activity to convey messages (ideas, feelings, and information) in written form to other parties. In this sense, there are indications that writing activity, in addition to being part of the thought process as described above, is also seen as a social process. A good writer will realize who the prospective reader is, so the language he employs is adjusted to the characteristics of his prospective readers. 
A scientific paper is a written work that presents ideas and problem-solving orientations written objectively by using standard language based on facts and empirical evidence. The presentation of the writing is bound to a standardized structure. This statement is in line with the opinions expressed by Brusaw et al. (1982) and Warriner (1977). Brusaw et al. state that scientific works are written works that convey ideas and problem-solving work in a standard language supported by facts and empirical evidence. According to Brusaw et al, there are six elements that need considering when writing scientific works: (1) selecting and limiting topics, (2) providing sufficient data, (3) identifying materials to be written, (4) classifying data, (5) determining the writing framework, (6) and composing a writing strategy.

As part of the type of writing, writing scientific work is also seen as a process carried out by someone. Writing scientific work means doing an activity that is active, constructive, and social. Considering the process, it involves complex physical and psychological aspects. Physically, the writing process that is done by someone can be observed directly through the product of the writing.

In addition, writing scientific papers is part of a continuous process of thinking, seeing, observing, and reviewing (Temple, et al. 1988: 19). Starting from this view, it can be said that the activity of writing and thinking is a process that cannot be separated. It is further confirmed by Tempel et al. that thinking is the basis for someone to be able to write that takes place before writing, during writing, and after writing. The thought process that occurs before someone does writing activities is remembering, connecting, predicting, and imagining. The process of thinking during writing is organizing, compiling, constructing, analyzing, and synthesizing. The thinking process after writing includes monitoring, reviewing, evaluating, and implementing.

Writing - including writing scientific papers - is a series of activities carried out with stages of preparation, development of the content, and improvement of the writing. These three stages are seen as an interrelated process. As a process, Barrs (1983), Ellis (1989), Proett and Gill (1986) group writing activities into several phases that include prewriting, drafting, revising, and editing. Each writing stage is an integrated writing step. It means writing activities are very possible to be carried out in each phase simultaneously. In the pre-writing and drafting stages, for example, both reviewing and revising activities can take place. Moreover, when the activity takes place at the writing stage, the content framework can be improved. This phase, according to Tomskin and Hosskison (1995), aims at developing the content so that what the writer wants to write can be well designed. The pre-writing phase includes the activity of determining topics, considering the text's purposes, paying attention to targets, gathering supporting information, and organizing ideas and information.

The phase of writing a scientific work begins after the pre-writing element is complete. The structure of the scientific paper writing consists of the initial part, the content section, and the final part. The initial section serves to explain the importance of the topic chosen and provides an overview of the scientific project in order to attract the attention of the reader. In detail, this section describes what, why, benefits, goals, and the scope of the writing. The contents section presents the development of ideas supported by elements that can clarify ideas such as pictures, illustrations, information, evidence, or reasons. The final part of the scientific essay serves to remind the reader of the main ideas written. This section is a summary or emphasis on important ideas and it can be in the form of conclusions and suggestions. When the writing is finished, the next step to carry out is to check, supervise, and refine the text so that the writing will be of good quality.

The post-writing phase includes editing and revising activities. Editing is the activity of rereading the paper with the intention to feel, judge and examine the mechanical elements or even the contents of the paper. Based on the results of editing, revising activities are carried out. The revision can be in the form of additions, replacements, omissions, or rearrangement of elements of the paper. The different notion of editing and revising is in line with the opinion of Hefernan and Lincoln (1990) and Tomskin and Hosskisson (1995); editing is examining the written work and paying attention to the mechanical elements of writing such as spelling, punctuation, diction, sentence, paragraph, language style, citation, and other writing conventions. Revising is more focused on checking and improving the contents of the written work.

\section{METHOD}

This study employed a modification of two models of development design in learning, namely, R2D2 (recursive, reflective, design, and development) and RDR (research development research). Willis (1995) 
divides the stages in the R2D2 model into three stages, namely, (1) the stage of determination, (2) the stage of determining design and development, and (3) the stage of dissemination. The modified form of the R2D2 model consists of only two stages, namely, the stage of determination and the stage of determining design and development. Borg and Gall (2003) divide activities in RDR model into three main steps, namely, (1) preliminary research, (2) development of learning devices, and (3) implementation of product effectiveness through testing activities. Figuring out the effectiveness of teaching materials through testing activities is important because the purpose of this research and development is to determine the effectiveness of products in real learning situations. The modified form of the RD model entails two stages, namely, developing learning devices and determining product effectiveness through testing activities. Hence, the modification of the R2D2 and RDR models used in this study include (1) preliminary study, (2) focus of determination, (3) focus of development design, and (4) product effectiveness test. The preliminary study phase and focus of determination were carried out in the $1^{\text {st }}$ year while the focus of the development design and effectiveness test were carried out in the $2^{\text {nd }}$ year.

The development of the modified R2D2 and RDR learning models are in accordance with the objectives of this research and development, that is developing teaching materials for scientific paper writing and testing the effectiveness of teaching materials for scientific paper writing for polytechnic students. The research procedure can be described as follows.

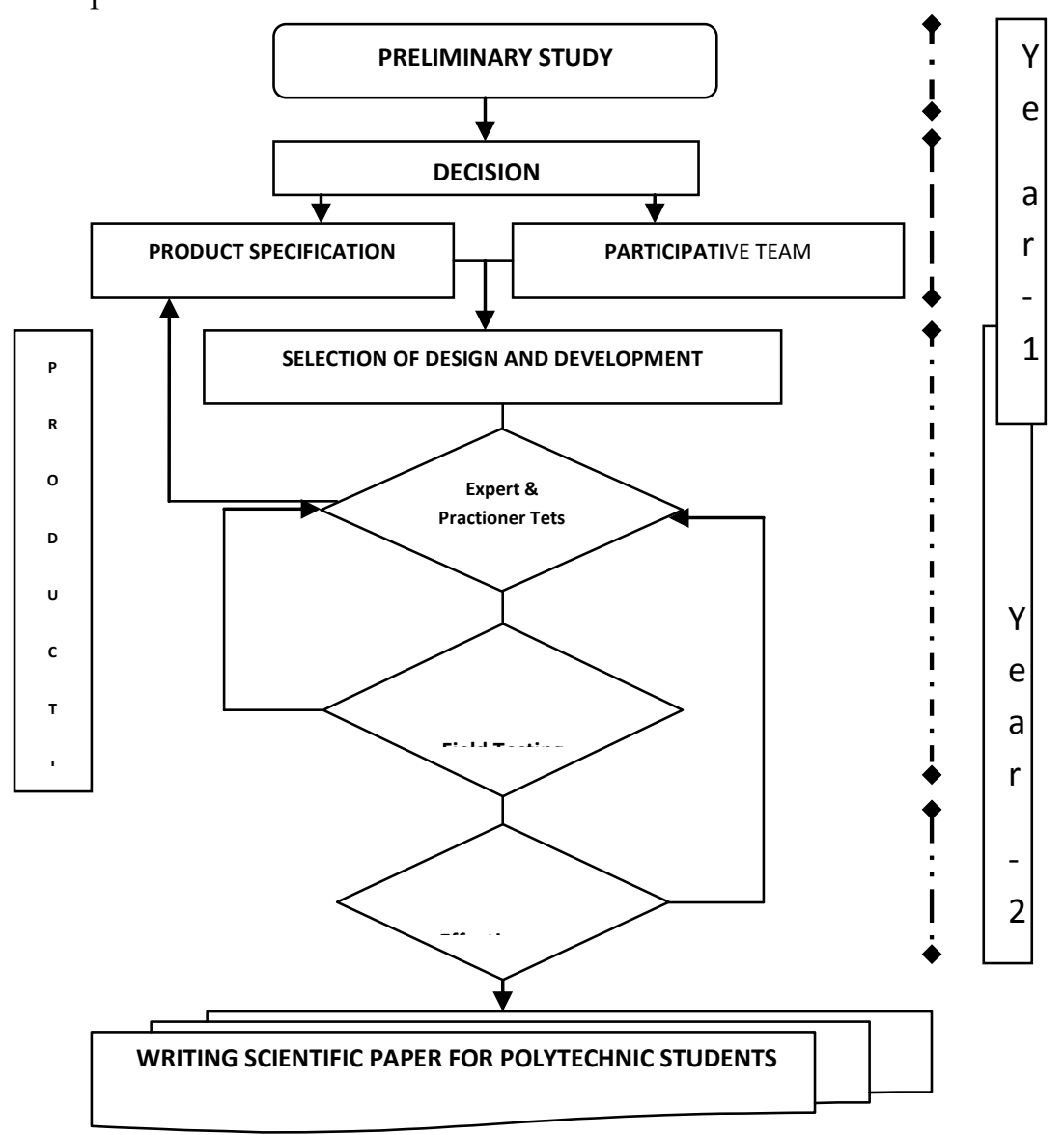

Figure 3: Research Procedures

The research data are in the form of (1) the results of expert and practitioner review, (2) the results of the product trials, (3) the revision of the product, and (4) the product effectiveness test. Review of experts and practitioners is taken by completing the assessment instruments for the teaching material products; (3) Data from students are elicited by administering interviews with the students based on interview guides that have been made; (3) The effectiveness test is carried out by performing pretest and posttest in the learning process by utilizing the teaching materials. 


\section{FINDINGS AND DISCUSSION}

\section{Review from Experts and Practitioners}

In accordance with the review of the teaching materials by vocational learning technology experts, the product is deemed to be appropriate for use in learning. Moreover, the product has been revised by improving the teaching materials for scientific work writing in accordance with comments and suggestions received from the experts. Viewed from the aspect of the feasibility of the content presentation, in general (1) the material presented in the teaching material is in accordance with the objectives and reflects the steps that supports the achievement of the objectives; (2) the presentation of the concept is sufficient because this teaching material is well prepared so that the students can write scientific work, not to learn about scientific paper; (3) examples and cases are presented in accordance with the real contexts and situations in the Polytechnic; (4) practical tasks have been given in groups and individuals; and (5) the steps for writing scientific work can be carried out well by students.

Related to the techniques used to support the presentation, this teaching material is deemed to be feasible. This can be seen from the results of the review given by the experts; (1) the systematic presentation in each chapter is consistent and has reflected vocational learning; (2) learning objectives presented in a special section can generate learning motivation; (3) the existence of marginal notes in the observation text supports students' understanding of specific parts of the text; (4) the use of personal pronoun "Anda" reflects the involvement of students with learning; (5) the method used reflects the characteristic of vocational learning, which is based on practice starting from observation, structured steps, and the practice of writing scientific papers itself.

This teaching material has been developed with clear steps, constructed in accordance with learning steps at the Polytechnic. Vocational learning is characterized by practical activities and they have been implemented in this teaching material. What needs to be added is a marginal note on observing activities. The review given by learning technology experts is used as the main consideration in refining the teaching material products. Two key elements that need revising include (1) practical assignments should not be provided only for individuals but also for groups, (2) and marginal notes for each observed material should be added.

Based on the review given by Indonesian language learning experts, the teaching material for scientific paper writing for vocational students, in general, is deemed to be appropriate for use in learning. The material presented is quite complete in supporting the achievement of the learning objectives. The material presented starts with the introduction of concepts, procedures, examples, practices, and interconcept interactions, all of which are quite in accordance with what is mandated by the objectives. Examples of elements of scientific work should be more varied so that the analysis carried out by students is more in-depth. Descriptions, procedures, practices presented have been designed with questions or things that interest students' curiosity. Practical tasks for individuals and groups have been implemented. The presentation approach has been directed to inquiry/experiment methods and each chapter already contains practice activities. Evaluation serves as feedback and can measure the students' competency and evidence is added if the students answer "yes". The existence of observing samples, knowing the steps to support the practice of writing, and evaluating the work with a very clear rubric indicates that the product, in general, is ideal for polytechnic students.

In addition, based on the review given by the practitioner in vocational education, the teaching material is generally stated to be suitable for use in learning. The teaching material is in accordance with the learning objectives. The material is accurate because it outlines all necessary steps that support all learning objectives. Examples of scientific texts accompanied by marginal notes tickle the students' curiosity and this situation fosters their learning motivation. Practical activities followed by discussions and reinforcement from lecturers can create a pleasant learning atmosphere. Systematic presentation of each chapter is very consistently proven and each chapter starts with concept maps, observations of scientific works, procedures for writing a scientific paper, the practice of writing scientific papers, and assessment of the written work by the students themselves. Most concepts are presented concretely so that the students find it easier to recognize, analyze, and draw conclusions. The teaching material is practice-based and other learning activities such as observing, designing, understanding steps, and evaluating ones' own work serve as supporting activities. General comments from practitioners, among others, are (1) one of the advantages of this teaching material is the distinctive features of the learning steps; (2) the developer is able to manifest the characteristics of vocational learning in this teaching 46 | ISLLAC : Journal of Intensive Studies on Language, Literature, Art, and Culture 
material; (3) the students find it easy to write scientific papers because most of the learning steps are concrete; and (4) this teaching material does not teach about scientific paper, but it teaches the students to write scientific paper themselves.

\section{Results of Product Trial}

The teaching material for scientific work writing can help achieve the competence of writing scientific papers. The following are some things related to the product.

1) In general, each chapter in the book contains observing activities, working on scientific work based on predetermined steps, and assessing the results of compiled scientific works based on instruments. 58\% of students find the book very helpful, $37 \%$ of them find it helpful, and $5 \%$ of them find it quite to help them master the skills of writing scientific papers.

2) Related to the students' understanding of the concept and its application in writing scientific work, it can be concluded that $66 \%$ of the students have high understanding, $25 \%$ understand, $4 \%$ understand enough, and $4 \%$ do not understand.

3) Students feel that the learning carried out in this book is fun as the atmosphere of learning in a workshop or laboratory. $66 \%$ of the students state that the book is highly enjoyable, $29 \%$ enjoyable, and $4 \%$ quite enjoyable.

4) After working on all the activities in this book, when asked about writing scientific papers at any time, $87 \%$ of the students feel very confident, $8 \%$ confident, and $4 \%$ not sure.

5) Related to learning strategies in the teaching material presented in each chapter, $70 \%$ of the students state that the book is very helpful and $29 \%$ of them state that the book helps them master the skills of writing scientific papers.

6) Related to the students' general responses towards the provision of the teaching material, about $91 \%$ of the students state that they are very happy about the provision of the book, $4 \%$ happy, and $4 \%$ quite happy.

7) Related to the classroom atmosphere when using this teaching material, $20 \%$ of the students find it very pleasant, $37 \%$ pleasant, and $41 \%$ pleasant enough.

\section{Revising the Product}

\section{Descriptions of the Teaching Material}

In this section, the discussion of the teaching material for writing scientific work for vocational students is provided consisting of: Learning Components; Chapter 1: Writing Scientific Work; Chapter 2: Writing Quotations and Reference Lists; Chapter 3: Editing Languages in Scientific Work. The discussion of the results of teaching material in each chapter is presented as follows.

\section{Learning Components}

As explained in the description of the results, in general, this section contains instructions on how to use the book. This section is the same as the guideline for implementing learning which has an important position in learning. Therefore, it needs to be carefully prepared so that the learning process can reach the goal. The intended target is the competencies that must be achieved by students, which is being able to write a scientific paper.

The learning implementation guide has a strategic function for students and lecturers. For students, the guide to implementing learning can direct all learning activities. For lecturers, the learning guidelines can be used as directions for their activities in the learning process and guidelines for carrying out evaluation activities on the achievement of the learning outcomes.

The developed learning guide supports the learning process of vocational education. This can be seen from practical activities that characterize vocational learning. This statement is in line with the opinion of Moodie (2008) that vocational learning emphasizes practical activities. In its implementation, vocational learning can be seen in student activities during the learning process. The practice of writing a scientific paper begins with observing concept maps, observing examples, understanding concepts, and writing practice based on the steps of writing scientific work. Practical activities are followed by assessing the results of the writing by utilizing available instruments. The role of the lecturer in the learning process is to provide reinforcement so that the students have a complete understanding of the concept of scientific work and assess the results of their own work. 
The purpose of developing the teaching material for writing a scientific paper for vocational students is to improve the students' competence in writing scientific work. Guidelines for implementing learning that is displayed in this section can be used to support these objectives. The guidelines for implementing good learning can improve the quality of the process and improve the quality of learning outcomes.

Based on the results of the product effectiveness test, the teaching material for writing a scientific paper for vocational students can effectively improve the students' competence in writing a scientific paper. The improvement can be seen from the scores of the pretest and posttest. The increase in posttest scores in the experimental class can be used as an indication that the quality of scientific work is increasing. The improvement of the quality of learning can be observed through increasing interactions that occur in the learning process. These interactions occur reciprocally between student-lecturers or lecturers-students through learning strategies.

The students' participation in the learning process has also increased. This can be seen from the observations done by the researchers and the students' responses to the use of instructional materials that have been developed. The skill of writing scientific papers needs to be seriously trained so that the students are able to write the scientific paper well because these skills can support the smoothness of achieving success in their studies at the Polytechnic as a vocational education institution. Many things can be done by students if they want to master the skills of writing a scientific paper including writing papers, writing articles, and writing reports. Furthermore, the students will be skillful in composing the final report or the thesis. The effectiveness of the product to improve the writing skills in scientific papers as described above is inseparable from the role of the learning guidelines developed.

\section{Writing Scientific Paper}

The competencies that must be mastered by students in Chapters 1-3 are that the students are able to write a scientific paper with the correct conventions. To achieve this goal, one of the learning methods used in modeling. Learning begins with observations of the existing scientific papers. The text under the observation is also accompanied by marginal notes that can help the students pay attention to specific new information. Take, for example, recognizing parts, structures, relationships, and contents of scientific work. This activity can function as a modeling activity for students in writing a scientific paper.

In vocational learning, modeling is considered more effective than other methods because modeling students will be able to produce the same product with something that is used as a model. The statement is the same as the opinion of Muijs and Reynolds (2008: 49) who state that modeling is more effective than verbal explanations. The modeling method described above has parallel meanings with the term proposed by Marahaimin (1994: 10), which is copy master. Marahaimin argues that at learning to write through rules is like learning to swim on land that will not make us able to swim skillfully. Furthermore, it is explained that the copy master method or modeling encourages the students to read the text carefully, review the contents and structures, analyze the framework, and do other necessary steps needed before they practice writing papers on their own. It also needs to be emphasized that what is written by students is not exactly the same as the model to avoid imitating or plagiarism.

Model text in learning to write a scientific paper can also act as learning media. Considering the nature of the observation text, it includes concrete media that can help provide a complete and most meaningful impression of the information and ideas contained in it. Azhari (1997: 11) reinforces this statement because concrete media involve many senses during the observation. Therefore, the media in the form of text can help strengthen knowledge, revive the learning at an osphere, guarantee a high level of understanding, and guarantee a long-lasting understanding.

In addition to modeling and learning media, the provision of learning materials also crucial to the success of writing a scientific paper. Learning materials for writing scientific papers are prepared by taking into account (1) the suitability with learning objectives and (2) selection of materials that includes the type, scope, sequence, and treatment. The subject of writing a scientific work has a strategic function for students and lecturers. For students, it is the substance of competence that must be mastered. For lecturers, it is the substance of competence that must be taught and is a guideline in carrying out the learning process. The learning material for writing scientific works can also be used as an ingredient to determine evaluation tools. Thus, it can be said that the learning material for writing scientific work has a big role in achieving learning success. This is consistent with the opinion of Tompkins (1990) stating that learning material is one of the determinants of the success of overall learning. In accordance with its 
strategic function, the learning material for writing a scientific paper is prepared by considering the content and organization of the presentation.

The content of learning to write scientific work is prepared based on needs analysis. In accordance with the needs analysis, learning objectives and learning materials for writing scientific papers are determined. The material for writing a scientific paper is studied by students through various activities, including understanding the theory of scientific work, observing the texts of scientific works, discussing, presenting, practicing, and evaluating the results of practice. In general, the presentation of learning material to write scientific work uses inductive patterns, in which the students build concepts independently through exploration and activities to apply concepts in the practice of writing a scientific paper.

As explained in the previous section, vocational learning prioritizes practical activities. This is in accordance with the learning theory for vocational students developed by Moodie (2008) and the characteristics of vocational learning proposed by Moodie (2008), Sofyan (2011), Hadi (2011), and Prosser (2011). Learning for vocational students has a correspondence with the process approach in the field of language developed based on the opinion of Badger \& White (2000) stating that learning based on process consists of a number of steps that emphasize the importance of practice. In the process, practical activities pay attention to activities such as observing, understanding steps and evaluating the results of the one's work. By paying attention to practical activities, the learning process of writing scientific paper is compiled by focusing on these learning steps: (1) understanding the nature of scientific work, (2) observing scientific paper, (3) designing scientific work, (4) understanding steps in writing scientific work, (5) practicing writing scientific paper, (6) and evaluating the results of the writing. The seven steps are explained in the following description.

First, understanding the nature of the scientific work presented in the teaching material aims at helping the students get information including the understanding of functions, characteristics, and benefits of scientific work. This understanding will lead to increased students' learning motivation to gain competence in writing a scientific paper. In learning theory, the success of students in reaching learning competencies is influenced by the role of motivation. This is in accordance with the opinion of Biggs and Tefler (1987) stating that learning motivation is strengthened by learning activities that can affect the learning process and the learning activities can be determined by the lecturer.

Second, it deals with observing model texts of scientific work. The activity aims to enable students to associate their understanding of the context of real situations; the process of observing involves seeking information, seeing, listening, reading, and listening. Observing the text of scientific work is an integral part of the steps of vocational learning. The activity of observing the text of scientific work is in the form of activities such as reading, finding elements, structures, and distinguishing forms. The approach used to observe the text of scientific work is individual work, followed by group discussions, and presentations. Input from other groups in the presentation and reinforcement activities by the lecturer can be used as an improvement material for the observation. Based on the description, observing activities will produce findings. This is in accordance with the theory of discovery learning developed by Bruner. There are four main things related to Bruner's learning theory (in Carin \& Sund, 1975): (1) the individuals only learn and develop their mind when they use their mind, (2) it is done by carrying out cognitive processes in the discovery process and intellectual satisfaction which is an intrinsic appreciation, (3) the only way for a person to learn the techniques of making discovery is that when he has the opportunity to make discoveries, and (4) by making discoveries it will strengthen memory retention. The four things above are compatible with the cognitive processes needed in practice-based learning.

Third, it deals with designing scientific work. In this stage of learning, learning activities are emphasized in the ability to draw up the framework of scientific work. The framework of scientific work helps students organize their ideas, avoid repeated ideas, and accelerate the students' writing of scientific work. On this matter, Wahab and Lestari (1999) clearly state that the author who has prepared an essay framework means that he has completed $75 \%$ of his writing because the writing process will run smoothly since the author is not preoccupied with structuring ideas and the language used is even more perfect.

Fourth, understanding the steps to write scientific work is an activity towards the practice of writing scientific papers. Considering its function, these steps are like a procedure that must be carried out so that the process runs efficiently and the results can be achieved perfectly. In practicum management 
procedures, this procedure is known as a standard operational procedure (POS). Thus, the steps to writing a scientific work function to form a system of workflow which is regular and systematic.

Fifth, the practice of writing scientific papers has the main purpose of helping students build a picture of the material of writing scientific work that has been previously followed. Regarding the purpose of the practice of writing this scientific work, Siberman (2006: 134) states that there are times when a number of concepts still cannot be understood although they have been explained verbally and visually. One way to help students build a picture of the material being taught is to practice it. The practice of writing a scientific paper is related to writing activities based on the steps of writing scientific work, including paying attention to linguistic aspects such as paragraphs, sentences, and correct spelling usage (Lee, et al. 2007). The accompanying activity is to discuss the results of the practice of writing with other students. The results of the discussion are used to revise the scientific work already written by the students. To ensure that this activity works effectively, the students are guided by structured steps to be carried out and questions to be answered.

The learning steps by paying attention to practical activities which are the main activities of vocational learning result in a learning process that focuses on students; this is done to create fun learning. Fun learning should be created because the success of learning is not determined by the curriculum, but is determined by educators to create a fun to learn atmosphere or joyful learning (Suprapto, Jawa Pos July $7^{\text {th }}, 2014$ ). A study conducted by C.E Beeby in 1970 (in Suprapto) concluded that the chronic problems of our education are also caused by boring classroom practices.

Sixth, the last step deals with assessing the results of practice. The activity carried out by students in this step is to fill in instruments that can be used to assess the work of students in each chapter of writing a scientific paper. This activity is conducted to find out the results of learning carried out by the students and can be used as feedback for lecturers to correct some weaknesses found during the learning process. This description is in line with the statement of Iskandarwassid and Sunendar (2008: 210) that evaluation can be used to determine the results achieved by the students. Evaluation can also be used by lecturers to know and correct learning problems. Evaluation is an inseparable part of the learning process and even evaluation is an important part of learning (Tuckman, 1975). Furthermore, Djiwandono (2008: 1) suggests that the evaluation of language learning is an effort to ensure the achievement of learning objectives that have been formulated. With evaluation, the students can find out the competencies they have achieved and can provide motivation to achieve better levels. For lecturers, the evaluation can be used to determine the competencies achieved by students and at the same time can be used to make appropriate decisions to determine the next steps. This is in accordance with the role of evaluation in exposure to professional curriculum services (Ministry of Education, 2003: 10): (1) playing a role to determine the students' work compared to the work of other students; (2) describing the level of mastery of the students towards the specified competencies; and (3) revealing learning difficulties experienced by students and possible achievements that can be developed. The characteristics of the evaluation developed are based on instruments consisting of two main elements. First, evaluating can be used to build concepts for the material being studied. In developing the concept, the students can work individually and in groups, present their work, and revise the results of their work. Comments and feedback from other students and reinforcement from lecturers are useful in improving the scientific paper. This opinion is in line with what has stated by Alwasilah (2010: 80): (1) feedback from other students (peer editing) and lecturers are useful for the improvement of the writing; (2) short discussions between students and lecturers and repeated draft writing (multiple drafting) can improve the quality of the writing. Second, it can be used to build skills while measuring student learning outcomes in the form of the final work of the learning process. In building the skills of writing a scientific paper, the students can work together in groups, be responsible for completing learning tasks, and revise the results of the practice of writing a scientific paper.

\section{Product Effectiveness Test}

This product effectiveness test is conducted to find out the results of product use in the form of teaching material for scientific paper writing for vocational students to improving the students' competence in writing a scientific paper. The description is in line with the opinion of Tomskin (1990) that knowing the effectiveness of the product is the same as knowing the success of the overall learning process. To test the effect of product use developed on the results of the learning process of writing scientific papers, experimental design is used. The data are in the form of pretest and posttest scores. 
The experimental activities are carried out through three stages, namely, (1) the pretest stage, to determine the initial level of the students' ability to write scientific paper, (2) the provision of treatment in the form of using teaching materials to write scientific works for vocational students that have been developed in the learning process, and (3) post-test implementation.

\section{Table 1: Results of t-Test in Writing Scientific Paper}
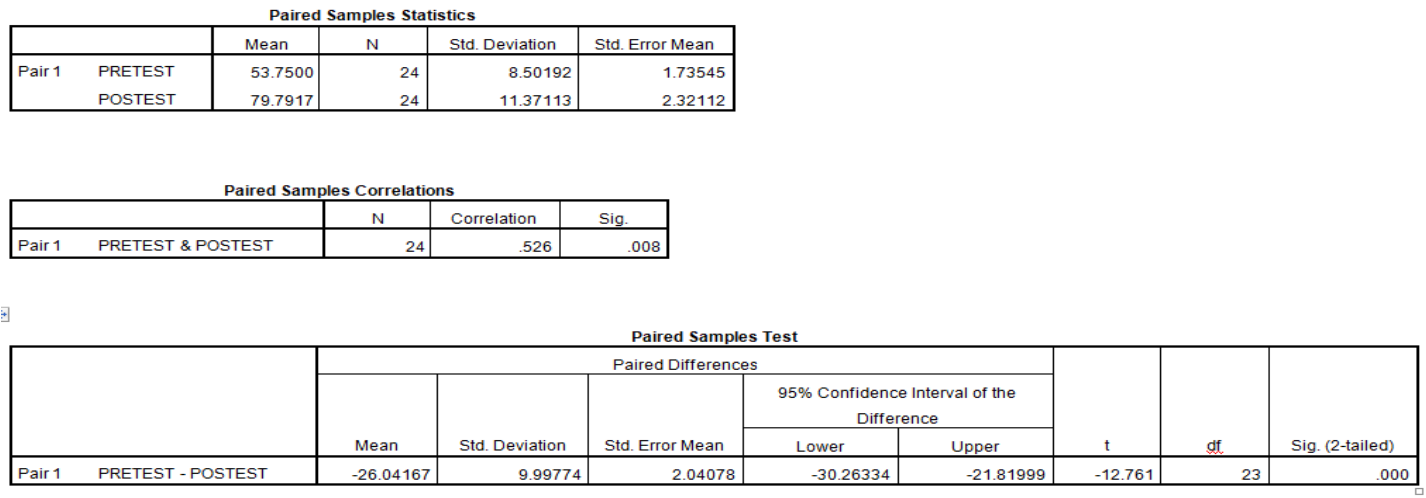

The results of testing the $t$ hypothesis with paired pretest and posttest data for writing a scientific paper show that null $\mathrm{H}$ is rejected, meaning the post-test results are better or more effective than the pre-test. This is indicated by the mean value of -26.04167 and the standard deviation of 9.99774 and the standard mean error of 2.04078. This result is very significant with the significance value indicator of 0.000 (below the alpha of 0.05).

Table 2: Results of t-Test for Writing Introduction Section

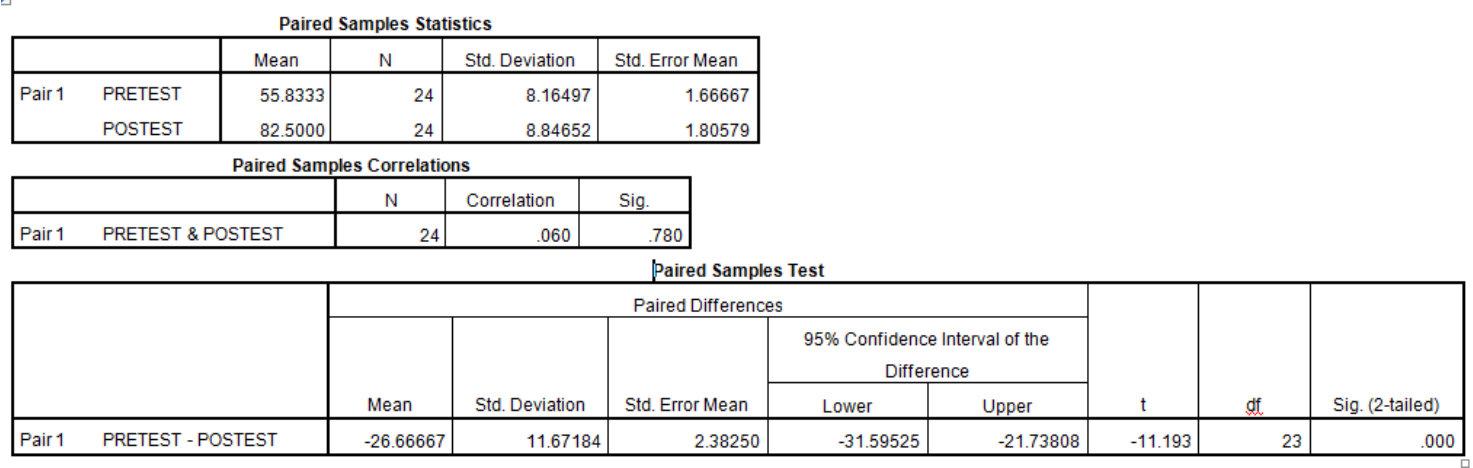

The results of the hypothesis test with data on pretest and posttest for the introduction section show that null $\mathrm{H}$ is rejected, meaning the posttest results are better or more effective than the pretest. This is indicated by the mean value of -26.66667 and the standard deviation of 11.67184 and the standard mean error of 2.38250. This result is very significant with the significance value indicator of 0.000 (below the alpha of 0.05). 
Table 3: Results of t-Test for Writing Discussion Section

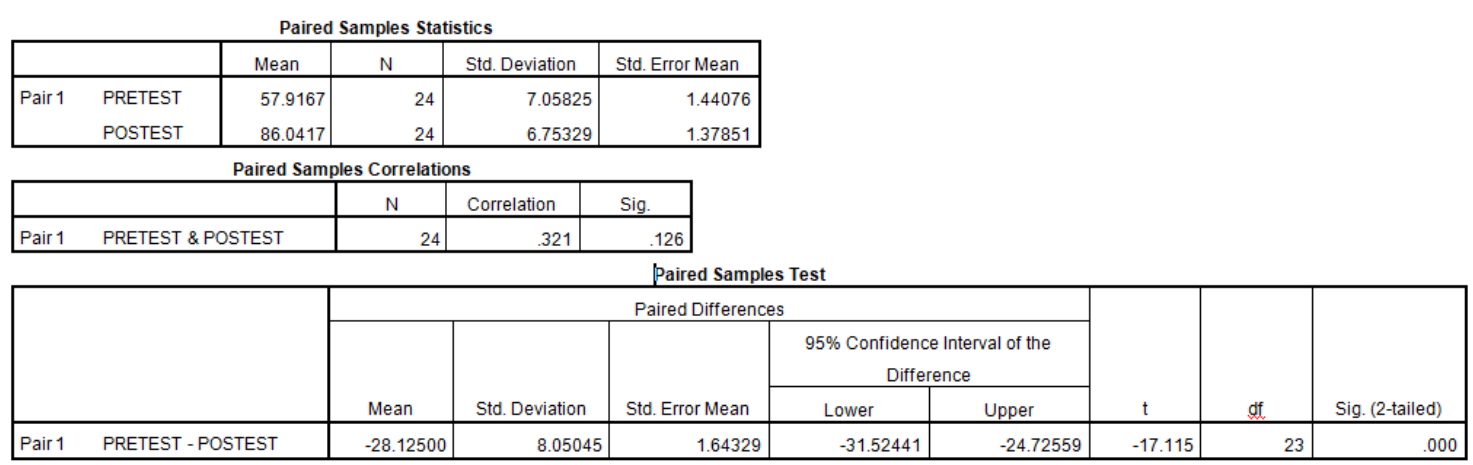

The results of the hypothesis test with paired pretest and posttest data for data analysis of discussion section show that the null hypothesis is rejected, meaning the posttest results are better or more effective than the pretest. This is indicated by the mean value of -28.12500 and standard deviation of 8.05045 and the standard mean error of 1.64329. This result is very significant with the significance value indicator of 0.000 (below the alpha of 0.05).

\section{Table 4: Results of t-Test for Writing Closing Section}

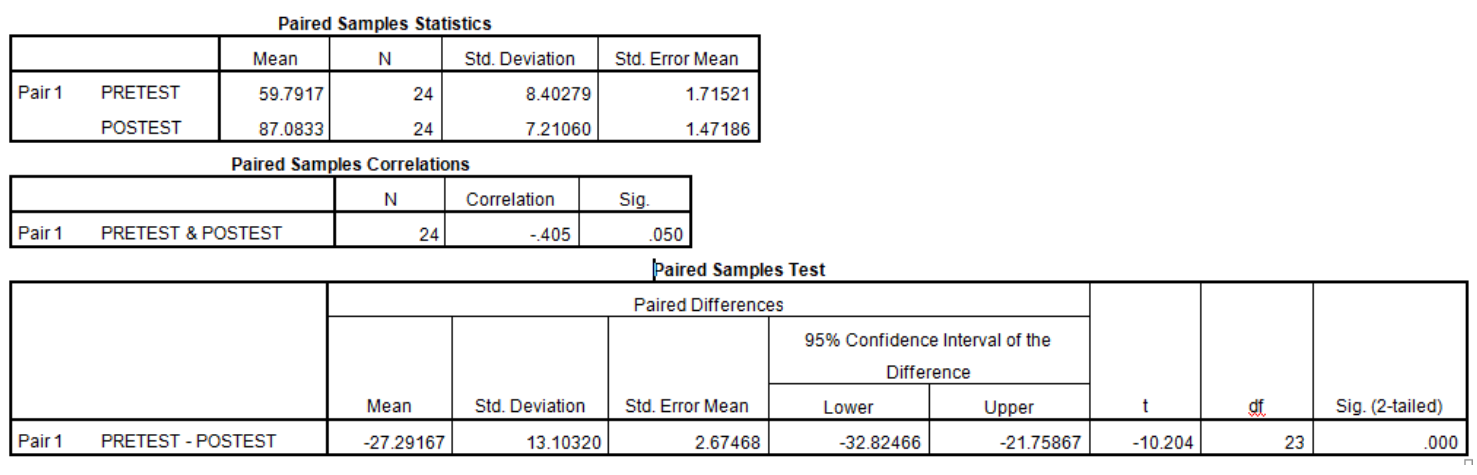

The results of $\mathrm{t}$ hypothesis test with data on pretest and posttest data for closing section indicate that null $\mathrm{H}$ is rejected. This means the posttest results are better or more effective than the pretest. This is indicated by the mean value of -27.29167 and the standard deviation of 13.10320 and the standard error of the mean is 2.67468 . This result is very significant with the significance value indicator of 0.000 (below the alpha of 0.05$)$.

Table 5: Results of t-Test for Writing Citations

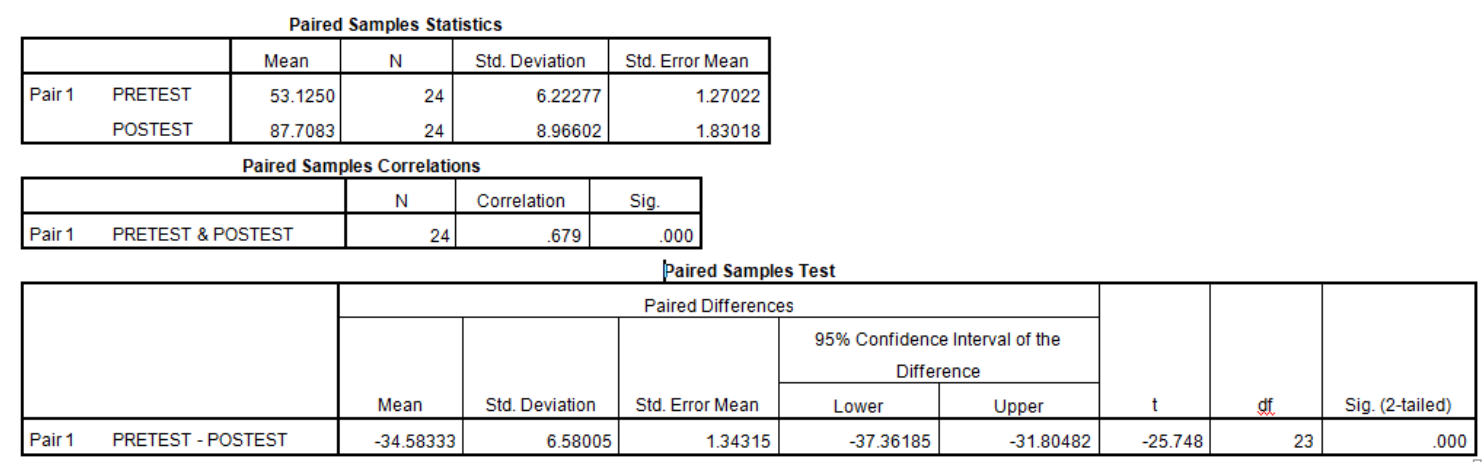

The results of $\mathrm{t}$ hypothesis test with pretest and posttest data for citation show that null $\mathrm{H}$ is rejected. This means the posttest results are better or more effective than the pretest. This is indicated by the mean value of -34.58333 and the standard deviation of 6.58005 and the standard mean error of 1.34315. This result is very significant with the significance value indicator of 0.000 (below the alpha of 0.05 ). 
Table 6: Results of t-Test for Editing Language

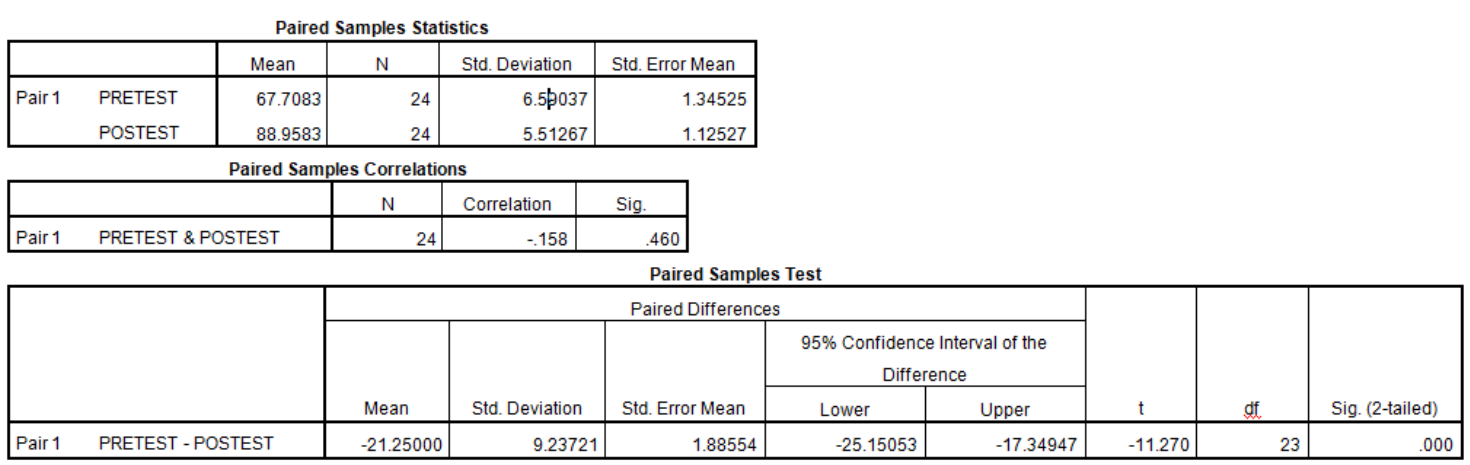

The results of $\mathrm{t}$ hypothesis test with pretest and posttest data for editing language indicate that null $\mathrm{H}$ is rejected. This means the posttest results are better or more effective than the pretest. This is indicated by the mean value of -21.25000 and the standard deviation of 9.23721 and the standard mean error of 1.88554IS. This result is very significant with the significance value indicator of 0.000 (below the alpha of $0.05)$.

\section{CONCLUSIONS AND SUGGESTIONS}

\section{Conclusions}

The specifications of teaching materials and teaching material for writing a scientific paper for polytechnic students are the products that have been yielded in this study. Teaching materials for scientific paper writing for polytechnic students contain 3 skills, namely, (1) writing a scientific paper, (2) quoting and writing reference lists, and (3) editing languages in scientific works.

The learning activities carried out in each skill consist of several activities: (1) observing the text, (2) understanding the steps of writing, (3) writing practice, (4) and assessing the results of writing practice. The product developed in this research and development is in the form of teaching material for writing scientific work that is suitable for polytechnic students. This can be seen from the practical activities that become the trademark. To support practical activities, the learning steps used are observing the text, understanding the steps to write scientific work, practicing writing scientific papers, and evaluating the results of the practice of writing scientific papers.

The teaching material for vocational-based scientific paper writing can increase the effectiveness of achieving the competence to write academic work for polytechnic students. This can be proven from the results of field trials and the results of product effectiveness tests.

\section{Suggestions}

Based on the results and discussion of the results of the research and development that have been presented, the following suggestions for utilization, desimination, and further research and development are presented.

The instructors of Indonesian language courses can use this product as one of the teaching materials in writing scientific papers for three reasons. First, it can be seen from its contents that research and development products can be academically and conceptually accountable. The learning process of writing scientific work can be accounted for academically and can be used to improve the ability to write scientific papers. Second, based on the results of the effectiveness test, it is known that the teaching materials for writing scientific works are able to improve the students' ability to write scientific papers.

Those in charge of Student-Led Academic Unit (UKM) can utilize research and development products as one of the models in developing scientific writing activities for the members of the UKM for two reasons. First, this research and development product offers teaching materials to write scientific works that are in accordance with the education system at the Polytechnic Institution. Second, this product of research and development offers to learn to write scientific works as a whole that starts with prewriting activities, writing activities, and post-writing activities. The three skills learned in this teaching material can improve the students' ability to write scientific work as a whole. 
The university staffs who are in charge of the development of learning at the Polytechnic, for example, P3AI or research and academic center, are suggested to use the results of this research and development as one of the models for developing teaching materials in the Polytechnic.

\section{REFERENCES}

Alwasilah, A. Ch. (2010). Filsafat Bahasa dan Pendidikan. Bandung: Sekolah Pascasarjana UPI dan PT Remaja Rosdakarya.

Ansary, H. and Babaii, E. (2002). A Step Toward Systematic Textbook Evaluation. Iran: Shiraz University, pp. 2.

Arsyad, A. (1997). Media Pembelajaran. Jakarta: PT Raja Grafindo Persada.

Biggs, J.B. (1987). The Proses of Learning. Sydney: Prentice-Hall of Australia

Borg, W.R and Gall, M.D. (2003). Educational Research An Introduction (7th Edition).New York: Longman Inc.

Borg, W.R. and Gall, M.D. (2003). Education Research. White Plains: Longman Inc.

Brusaw, C.T., Aired, G.J, dan Oliu, W.E. 1982. Handbook of Teaching Writing, Second Edition. New York: St.

Martin's

Press.

(Online),

(http://pustaka.ut.ac.id/website/index.php?option=com conten\&view $=$ articel\&id $=123$ ), retrieved at 8 Agustus 2012 .

Buzan, T. (2002). Mind Map. Jakarta: PT Gramedia Pustaka Utama.

Carin, A.A. dan RB Sund. (1975). Teaching Science Through Discovery, 3rd Ed. Columbus: Charles E. Merrill Publishing Company.

Cunningsworth, A. (1995). Choosing Your Coursebook, Oxford: Heineman, pp. 3-4.

Djiwandono, S. (2008). Evaluasi Bahasa. Malang: Penerbit UM.

Ellis, A. (1989). Elementary Language Art Instruction. New Jersey: Englewood Cliff.

Heffernan, JAW. dan Lincoln, JE. (1990). Writing: A College Handbook. New York: WW Norton \& Company.

Keputusan Direktur Jenderal Pendidikan Tinggi Departemen Pendidikan Nasional Republik Indonesia Nomor : 43/Dikti/Kep/2006 Tentang Rambu-Rambu Pelaksanaan Kelompok Matakuliah Pengembangan Kepribadian di Perguruan Tinggi.

Lee, KC., Goh, H., Chan, J. dan Yang, Y. (2007). Effective College Writing: Proses Genre Approach. Singapore: Mcgraw-Hill.

MacArthur, C.A. dan Fitzgerald, J. (2007). Best Practices in Writing Instructional. New York: The Guilford Press.

Marahaimin, I. (1996). Menulis Secara Populer. Jakarta: Pustaka Jaya.

Moodie, G F. (2008). From Vocational to Higher Education. England: McGraw-Hill House.

Muijs, D. dan Reynolds, D. (2008). Effective Teaching: Evidence and Practice> London: Published by Sage Publications.

Patrick, J.J. Highschool Governement Textbook, in ERIC DIGEST ED301532, Desember 1988.

Permendiknas RI Nomor 22 tahun 2007 tentang Penetapan Buku Teks Pelajaran yang Memenubi Kelayakan untuk Digunakan dalam Proses Pembelajaran. Jakarta: Departemen Pendidikan Nasional.

Prosser, C.A. Enam Belas Prinsip Pendidikan Vokasional. (http://1ptk.blogspot.com/2011/11/prinsippendidikan-vokasional-dari.html), diakses tanggal 12 Agustus 2013.

Suprapto, B. (2014). Tahun Ajaran, Kurikulum, dan Seragam Baru. Jawa Pos 7 Juli 2014 pp. 4. 
Suyitno, I., Susanto, G., Kamal, M., \& Fawzi, A. (2017). TEACHING MATERIALS AND TECHNIQUES NEEDED BY FOREIGN STUDENTS IN LEARNING BAHASA INDONESIA. ISLLAC: Journal of Intensive Studies on Language, Literature, Art, and Culture, 1(1), 52 70.

Temple, C. Ch.; R. Nahan; N Burn; and Temple, F. (1988). The Beginning of Writing. Boston: Allyn and Bacon Linc.

Thamrin, M. (2014). Menulis Bahan Ajar Menulis Karya Ilmiah bagi Mahasiswa Vokasional. Malang: Disertasi.

Tompkins, G E., and Hosskisson, K. (1995). language Arts Contents and Teaching Strategies. New York: Macmillan College Publishing.

Trilaksono, S. (2005). "Pendidikan yang Memberdayakan" Disampaikan dalam seminar pendidikan dalam rangka lounching Sekolah Alam Insan Mulia Surabaya tanggal 5 Desember 2005.

Tuckman, B.W.B. (1975). Measuring Educational Outcomes: Fondamental of Testing. New York: Harcourt Braca Javanovich.

Wahab,A. and Lestari. (1999). Menulis Karya Ilmiah. Surabaya: Penerbit Universitas Airlangga Press.

Warriner, J.E. (1977). Advance Composition: A Book of Models for Writing. Orlando-Florida: Harcourt Barce Javanovich Publishers. (online). (http://pustaka.ut.ac.id/website/index.php?option $=$ com conten\&view $=$ articel\&id=123), retrieved at 8 Agustus 2012.

Willis, J. (1995). A Recursive, Reflective Instructional Design Model Based Constructivist-Interpretivist Theory. Educational Technology, (online), 35 (6), 5-23, retrieved at 19 September 2012.

World Bank. (1989). Indonesia: Basic Education Study. Washington DC: World Bank. 